\title{
Use of Seaweed-Based Biostimulants in the Production of Seedlings of Pomegranates (Punica granatum)
}

\section{Jederson Virginio*}

Federal Rural University of Semiarido, Brazil

*Corresponding Author: Jederson Virginio, Federal Rural University of Semiarido, Brazil.

DOI: 10.31080/ASAG.2020.04.0786
Received: December 27, 2019

Published: January 30, 2020

(c) All rights are reserved by Jederson

Virginio.

\begin{abstract}
In the Brazil, the cultivation of pomegranate aroused interest in several producers of fruit, especially in the northeast. The objective of this study was to test the efficiency of the best dose of the extract of seaweed in the development of pomegranate trees seedlings. The experiment was conducted in a greenhouse at the Federal Rural University of Semi-Arid (UFERSA), Mossoro, RN. In the experiment, was used a randomized complete block design (RBD) with five doses $\left(0,2,4,6\right.$ and $\left.8 \mathrm{ml} \mathrm{L}^{-1}\right)$ of the seaweed extract and six replications; each experimental unit was composed of five plants. The application of bio-stimulant doses were started at 7 days after transplanting, and the extract applied in seven-day intervals with a syringe, pouring $15 \mathrm{ml}$ of solution near the base of each plant until the end of the experiment. At 120 days after sowing the characteristics were evaluated: shoot length, root and total (cm); number of sheets (unit/plant), lap diameter ( $\mathrm{mm}$ ), dry mass of the stalk, the leaf, the shoot, root system and total (g). For further growth, dry biomass yield and better quality of pomegranate trees seedlings in nurseries, it was observed that the dose of $4.0 \mathrm{~mL}$ of biostimulants, promoted greater seedling growth.

Keywords: Punica granatum L; Ascophyllum nodosum; Lithothamnium; Vegetative Propagation; Biostimulant
\end{abstract}

\section{Introduction}

Due to the lack of data on the development and establishment of pomegranate culture in Brazil, there is a need for studies to domesticate a species such as the climatic conditions of the region. And to meet the new demands, it is necessary to expand the production area and, as such, to produce uniform and vigorous quality seedlings (PAIVA., et al. 2015). In this sense, a seedling propagation and acquisition phase is fundamental for the establishment of the crop in the field, since low substrate fertility and plant nutrition are some of the most limiting problems and can be corrected with the use of soil extraction. seaweed as a biostimulant [1].

In Brazil, the use of seaweed in commercial crops, in general, is in full expansion requiring more accurate information regarding its proper use. These synthesize plant hormones and there are products based on macroalgae extracts, which are commercially used as biostimulants to increase agricultural production. As an example, we can mention commercial products based on Ascophyllum nodosum and Lithothamnium, which, due to their action similar to plant hormones, have been used for foliar or soil applications, including organic agriculture [2].

Thus, the objective of the present work was to evaluate the efficiency of the best dose of seaweed extract in the development of pomegranate seedlings.

\section{Method}

The experiment was conducted in a greenhouse ( $50 \%$ shading) of the Federal Rural University of Semi-Arid (UFERSA), Mossoró,
RN. The seeds of pomegranate were collected from fruits purchased in a supermarket in the municipality of Mossoró- RN (5o $11^{\prime} 31^{\prime \prime} \mathrm{S}$ and $37^{\circ} 20^{\prime} 40^{\prime \prime} \mathrm{W}$, average altitude of $18 \mathrm{~m}$ ), coming from the same batch and presenting complete maturation. The seeds were extracted and processed manually with the aid of a \# 1/4 mesh sieve to remove the sarcotesta.

In the experiment it was used a randomized block design (DBC), in a $2 \times 5$ factorial scheme (two commercial seaweed products with five doses - 0, 2, 4, 6 and $8 \mathrm{ml} \mathrm{L}^{-1}$ ) and six replications; Each experimental unit consisted of five plants.

Initially pomegranate seeds were sown in trays of 128 cells. After sowing, after 30 days, the seedlings were transplanted to black polyethylene bags $(15 \times 28 \mathrm{~cm})$, containing as substrate the soil mixture $(75 \%)$ and tanned corral manure (25\% of its volume), whose chemical analysis of the soil was performed in the laboratory of UFERSA.

Biostimulant dose applications were started 10 days after transplantation, and the extracts were applied every seven days with the aid of a syringe, applying $15 \mathrm{ml}$ of the solution to the neck of each plant until the end of the experiment. 12 applications. Two commercial seaweed products were used, on this occasion called Bio A and Bio B.

Bio A is the seaweed extract of species A. nodosum (Acadian ${ }^{\circledR}$ [Agritech - Canada]) composed of: $\mathrm{N}-8.12 ; \mathrm{P}, 6.82 ; \mathrm{K}=12.00$; Ca $=1.60 ; \mathrm{Mg}-2.03 ; \mathrm{S}-8.16 \mathrm{~g} \mathrm{~kg}^{-1} ; \mathrm{B}, 5.74 ; \mathrm{Cu}-13.60 ; \mathrm{Fe}-11.5 ; \mathrm{Mn}$ $=0.04 ; \mathrm{Zn}-24.40$ and $\mathrm{Na}-20000 \mathrm{mg} \mathrm{kg}^{-1}$; potassium hydroxide, 
with $61,48 \mathrm{~g} \mathrm{~L}^{-1}$ of water-soluble $\mathrm{K} 20 ; 69.60 \mathrm{~g} \mathrm{~L}^{-1}$ of total organic carbon (ACADIAM, 2016). Bio B is represented by Lithothannium kelp extract (Sprintalga ${ }^{\circledR}$ - Biolchim), composed of: NO3- - $15.2 \mathrm{~g}$ $\mathrm{L}^{-1}$, NH4 + -16.5 g L-1, Mo - $22.9 \mathrm{~g} \mathrm{~L}^{-1}, 190.5 \mathrm{~g} \mathrm{~L}^{-1}$ total organic carbon, soybean cake, liquid sodium hydroxide, sodium molybdate [3].

At 120 days after sowing were evaluated Features: shoot length, root and total (cm); number of sheets (pcs/plant) and neck diameter $(\mathrm{mm})$. The number of leaves was obtained by fully counting leaves expanded; the neck diameter was measured with digital caliper accurate to $0.01 \mathrm{~mm}$. To length of the shoot was measured from the neck of the plant to the apical bud; while the length of the root system was measured from neck of the plant to the apex of the largest root. At length measurements were performed with the aid of ruler graduated in centimeters. For statistical analysis purposes, the data obtained were submitted to analysis of variance (ANAVA) and Tukey test (5\%) for comparison of averages. When significant the data Quantitative data were submitted to polynomial regression $(\mathrm{P}<0.05)$. For the analyzes statistics we used the computer program ASSISTAT [4].

\section{Results and Discussion}

There was significant interaction for almost all growth variables analyzed, except for the length of the root system that obtained a midpoint of $46.25 \mathrm{~cm}$. For shoot length in seedlings of pomegranates, note that at doses of 6 and $8 \mathrm{ml} \mathrm{L}^{-1}$ of Bio A was statistically superior to Bio B, although there was no statistical difference between the doses of Bio A (Table 1). Already in relation at doses of 6.0 and $8.0 \mathrm{ml} \mathrm{L}^{-1}$ of Bio B, these influenced the growth of seedlings, showing a probable toxicity in the plant, which can best be seen in graph 1A. Similar response was also verified for the total length of pomegranate seedlings, where the highest average $(106.08 \mathrm{~cm})$ resulted from Bio $A$ in the dose of $6.0 \mathrm{ml} \mathrm{L}^{-1}$, which differed statistically from the Bio B by more than $26 \%$ (Table 1 ). The doses of 6.0 and $8.0 \mathrm{ml} \mathrm{L}^{-1}$ of Bio B also influenced the total length of seedlings (Figure 1).

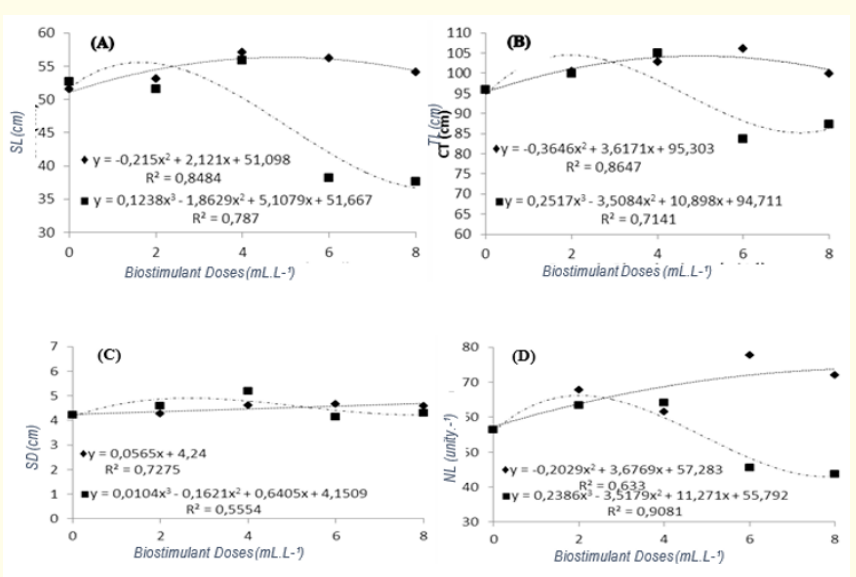

Figure 1: Doses of biostimulants in shoot length (SL) (A), total length (TL) (B), stem diameter (SD) (C) and number of leaves (NL) (D) of pomegranate seedlings.

\begin{tabular}{|c|c|c|c|c|c|}
\hline \multicolumn{6}{|c|}{ DOSES (ml.L $\left.\mathrm{L}^{-1}\right)$} \\
\hline $\begin{array}{l}\text { Bio } \\
\text { Stimulant }\end{array}$ & & & SL $(\mathrm{cm})$ & & \\
\hline & 0,0 & 2,0 & 4,0 & 6,0 & 8,0 \\
\hline$A$ & $51,62 \mathrm{aA}$ & 53,13 aA & $57,06 \mathrm{aA}$ & $56,21 \mathrm{Aa}$ & $54,09 \mathrm{aA}$ \\
\hline \multirow[t]{2}{*}{$B$} & $52,62 \mathrm{aA}$ & $51,61 \mathrm{aA}$ & 55,93 aA & $38,17 \mathrm{Bb}$ & $37,62 \mathrm{bB}$ \\
\hline & & & $\mathrm{TL}(\mathrm{cm})$ & & \\
\hline$A$ & $95,84 \mathrm{aA}$ & $100,38 \mathrm{aA}$ & $102,81 \mathrm{aA}$ & $106,08 \mathrm{aA}$ & 99,99 aA \\
\hline B & $95,84 \mathrm{aABC}$ & $99,97 \mathrm{aAB}$ & $105,05 \mathrm{aA}$ & $83,64 \mathrm{Bc}$ & $87,34 \mathrm{bCB}$ \\
\hline \multirow[t]{2}{*}{\begin{tabular}{|l|} 
Bio \\
Stimulant
\end{tabular}} & & & $\mathrm{SD}(\mathrm{mm})$ & & \\
\hline & 0,0 & 2,0 & 4,0 & 6,0 & 8,0 \\
\hline A & $4,22 \mathrm{aA}$ & 4,26 aA & $4,60 \mathrm{bA}$ & $4,67 \mathrm{aA}$ & 4,58 Аа \\
\hline \multirow[t]{2}{*}{$\mathrm{B}$} & $4,22 \mathrm{aB}$ & $4,59 \mathrm{aAB}$ & $5,20 \mathrm{aA}$ & $4,13 \mathrm{bB}$ & $4,30 \mathrm{Ab}$ \\
\hline & & & $\begin{array}{c}\mathrm{NL} \\
\text { (Unity: }^{-1} \text { ) }\end{array}$ & & \\
\hline A & $56,49 \mathrm{aB}$ & $67,82 \mathrm{aAB}$ & $61,52 \mathrm{aAB}$ & 77,68 aA & $72,10 \mathrm{aAB}$ \\
\hline$B$ & $56,49 \mathrm{aAB}$ & $63,38 \mathrm{aA}$ & $64,05 \mathrm{aA}$ & $45,53 \mathrm{bB}$ & $43,70 \mathrm{Bb}$ \\
\hline
\end{tabular}

Table 1: Interaction of biostimulant doses on shoot length (SL), total length (TL), stem diameter (SD) and number of leaves

(NL) of pomegranate seedlings.

Equal letters, uppercase lines and lowercase columns do not differ by Tukey's test at $5 \%$ probability of mistake.

The effect of Bio A ( $6.0 \mathrm{ml}$ dose $\left.\mathrm{L}^{-1}\right)$ on the seedlings of pomegranate trees may be related to its composition. These algae have in their constitution important phytohormones (cytokines and gibberellins), which may be interacting in cell division and stretching in Pomegranate seedlings. Oliveira., et al. [5] testing doses of A. nodosum-based compound in the production of passion fruit seedlings was observed better plant growth in dosage $3.67 \mathrm{ml} \mathrm{L}^{-1}$. The same authors attributed this effect the composition of the compound as there are cytokine in the natural form of algae, promoting increments in cell division and consequently greater plant growth.

Other authors testing doses of biostimulants also observed positive responses to growth fruit seedlings, such as papaya [6,7] and tangerine [8].

For the diameter of the seedling neck of pomegranates, it is observed that the highest average was resulting from Bio B and at a dose of $4.0 \mathrm{ml} \mathrm{L}^{-1}$, which had increments of more than $23 \%$ compared to with the witness (Table 2). This same dose was statistically superior to that of Bio A, showing that the composition present in product $B$ is shown higher for that variable. This effect may be related to the composition of Bio B, which by When treating other seaweed, it must be in its composition a higher proportion of gibberellins, which according to Taiz and Zeiger [9], promotes the cell division and stretching. The employment of combination of plant regulators (gibberellin and cytokine) in the development of seedlings of passion fruit allows an increase in the values diameters, which in practical terms means easier grafting [10]. 


\begin{tabular}{|c|c|c|c|c|c|c|c|c|c|c|c|c|c|}
\hline \multirow{2}{*}{$\begin{array}{l}\text { Sources of } \\
\text { Variation }\end{array}$} & \multirow{2}{*}{ DF } & \multicolumn{12}{|c|}{ Mean Squares } \\
\hline & & LAP & LRS & TL & ND & NL & DMS & DLM & DRM & DMAP & TDM & DRM/DMAP & DQI \\
\hline Bioest. (B) & 1 & $828,9^{* *}$ & $9,02 \mathrm{~ns}$ & $665,1^{* *}$ & $0,006 \mathrm{~ns}$ & $2340,7^{* *}$ & $1,6^{* *}$ & $0,1 \mathrm{~ns}$ & $0,2 \mathrm{~ns}$ & $3,1^{* *}$ & $4,7^{*}$ & $0,21^{* *}$ & $0,0001 \mathrm{~ns}$ \\
\hline Doses (D) & 4 & $219,0^{\text {** }}$ & $29,2 \mathrm{~ns}$ & 218,3 * & $0,76^{* *}$ & $163,7 \mathrm{~ns}$ & $1,1^{* *}$ & $0,2 \mathrm{~ns}$ & $0,8^{* *}$ & $2,8^{* *}$ & $6,4^{* *}$ & $0,03 \mathrm{~ns}$ & $0,04^{* *}$ \\
\hline $\mathrm{B} \times \mathrm{D}$ & 4 & $243,0^{* *}$ & $32,6 \mathrm{~ns}$ & 335,4 ** & $0,63 * *$ & $814,4^{* *}$ & $0,6^{* *}$ & $0,3^{*}$ & $0,1 \mathrm{~ns}$ & $1,6^{* *}$ & $2,3^{*}$ & $0,09 * *$ & $0,01 \mathrm{~ns}$ \\
\hline Treatments & 9 & $297,4^{* *}$ & $28,5 \mathrm{~ns}$ & $319,9^{* *}$ & $0,62 * *$ & $694,8^{* *}$ & $0,9 * *$ & $0,2^{*}$ & $0,4^{* *}$ & $2,3^{* *}$ & $4,4^{* *}$ & $0,07^{* *}$ & $0,02^{* *}$ \\
\hline Error & 45 & 30,4 & 18,69 & 60,3 & 0,14 & 100,88 & 0,14 & 0,09 & 0,12 & 0,31 & 0,72 & 0,01 & 0,005 \\
\hline CV (\%) & & 10,87 & 9,2 & 7,95 & 8,47 & 16,5 & 23,98 & 29,95 & 19,36 & 21,92 & 19,69 & 16,36 & 19,7 \\
\hline
\end{tabular}

Table 2: Summary of the analysis of variance of the effect of dosages of biostimulants on the production of pomegranate seedlings. Mossoró-RN, 2016.

**: Significant effect by the $\mathrm{F}$ test at the $1 \%$ probability level.

Note: DC: Neck Diameter; NF: Number of Leaves; LAP: Length of the Aerial Part; LRS: Length of the Root System; TL: Total Length; DMS: Dry Mass of the Stem; DLM: Dry Leaf Mass; DLR: Dry Root Mass; DMAP: Dry Mass of the Aerial Part; TDM: Total Dry Mass; DRM/DMAP: Root and Shoot Relationship; DQI: Dickson's Quality Index.

NS: Not Significant.

Regarding the number of leaves, the highest average was obtained from the $6.0 \mathrm{ml} \mathrm{L}^{-1}$ dose of Bio A, with an increase of over $42 \%$ compared to the witness (Table 2). This same dose was statistically higher than the other doses and 3 superior to product B. As auxins and cytokines (growth hormone) may be identified and quantified in the algae extract, these compounds influence the movement of nutrients to the leaf, playing an important role in source-drain regulation [9]. Oliveira., et al. [5] using seaweed extracts production of passion fruit seedlings yellow there was an increase of leaves at As doses were increased to $4.05 \mathrm{ml} / \mathrm{l}$ of compound. Already Guimarães., et al [7], working with the use of the extract from (Raiza ${ }^{\circledR}$ ) in the development of seedlings of papaya, found that there was a positive effect of algae doses on the number of leaves. In general, doses starting at $6.0 \mathrm{ml} \mathrm{L}^{-1}$ of biostimulant $B$, limits the development of seedlings of pomegranates, while the dose of $6.0 \mathrm{ml} \mathrm{L}^{-1}$ of biostimulant A promotes better development of pomegranate seedlings. So the contribution of the use of seaweed extract in the development of fruit seedlings emerges as a an alternative to the use of chemical inputs [11-13].

\section{Conclusion}

Seaweed Extract Ascophyllum nodosum at a dose of $6.0 \mathrm{ml} \mathrm{L}^{-1}$ promoted a greater growth and numbers of pomegranate leaves. For a larger increase in the diameter of the stem in pomegranate seedlings, it is recommended to use of seaweed extract lithothannium, at a dose of $4.0 \mathrm{ml} \mathrm{L}^{-1}$.

\section{Bibliography}

1. Norrie J. "Advances in the use of Ascophyllum nodosum sea plant extracts for crop production". Laboratory and Field Research (2008).

2. Stirk WA., et al. “Cytokinins in macroalgae”. Plant Growth Regulation 41 (2003): 13-24.

3. BIOLCHIM. Sprintalgas (2016).

4. Silva FAS and Azevedo CAV. "A new version of the assistat-statistical assistance software". In: World Congress on Computers in Agriculture, Orlando. Anais, American Society of Agricultural Engineers (2006).
5. Oliveira LAA., et al. "USO do extrato de algas (ascophyllum nodosum) na produção de mudas de maracujazeiro-amarelo". Revista verde de Agroecologia e Desenvolvimento Sustentável 6 (2011): 01-04.

6. Hafle OC., et al. "Produção de mudas de mamoeiro utilizando Bokashi e Lithothamnium". Revista Brasileira de Fruticultura 31 (2009): 245-251.

7. Guimarães IP., et al. "Avaliação do efeito do uso do extrato de alga ( raiza $^{\circledR}$ ) no desenvolvimento de mudas de mamão". Enciclopédia Biosfera 8 (2012): 312-320.

8. Souza JMA., et al. "Efeito de bioestimulante no desenvolvimento inicial de plântulas do porta- enxerto cítrico tangerineira 'Cleópatra'”. Scientia Plena 9 (2013): 1-8.

9. Taiz L and Zeiger E. Fisiologia vegetal. Porto Alegre, Artmed (2009): 819.

10. Oliveira A., et al. "Efeito de reguladores vegetais no desenvolvimento de mudas de Passiflora alata Curtis". Revista Brasileira de Fruticultura 27 (2005): 9-13.

11. CADIAN AGRITECH. Ciência das Plantas (Site Institucional) (2009).

12. Donadio LC. "Principais Frutas exóticas". In: Congresso Brasileiro De Fruticultura 20., Vitória, 2008. Anais. Espírito Santo (2008): 3.

13. IBRAF. Instituto Brasileiro de Frutas.

\section{Assets from publication with us}

- Prompt Acknowledgement after receiving the article

- Thorough Double blinded peer review

- Rapid Publication

- Issue of Publication Certificate

- High visibility of your Published work

Website: www.actascientific.com/

Submit Article: www.actascientific.com/submission.php

Email us: editor@actascientific.com

Contact us: +919182824667 